\title{
Rebooting the Cab Rank Rule as a Limited Universal Service Obligation
}

\section{Andrew Higgins*}

\begin{abstract}
This article critically examines the value and scope of the cab rank rule in England and Australia. Despite the laudable non-discrimination principle underpinning it, the cab rank rule is subject to so many exceptions it is debatable whether the rule has any effect, positive or negative, on access to justice. On the other hand, when the rule is followed, it has the potential to unnecessarily distort the legal services market.

Despite legitimate questions about its continued relevance, the paper argues that the rationale for the cab rank rule remains critically important in an age where most people are unable to afford private legal representation and are ineligible for public legal assistance.

The cab rank rule could play a greater role in delivering access to justice for all, by "rebooting" it as a limited universal service obligation to provide legal representation for all who genuinely need it but cannot obtain it privately. In practice this would involve the creation of a compartmentalized public cab rank in which all practising lawyers dedicate a small percentage of their billable hours to representing eligible clients for a regulated fee.
\end{abstract}

\section{Keywords}

Legal Profession - Discrimination - Access to Justice - Legal Services Market - Universal Service Obligations

*Associate Professor of Civil Procedure, Faculty of Law and Mansfield College; Barrister, Victorian Bar. Correspondence to: Andrew.higgins@law.ox.ac.uk The author would like to thank Adrian Zuckerman and John Flood for comments on an earlier version of the article. The usual disclaimers apply. 


\section{Introduction}

This article provides a critical re-examination of the cab rank rule in both England and Australia; its value and effects in practice, and ultimately its potential in promoting access to justice in an era where increasing numbers of people are unable to secure any legal representation. There are subtle differences in the scope of the cab rank rules in the bars in England and the various Australian states, but the basic principles are the same. The cab rank rule provides that a self-employed barrister cannot refuse a brief within their area of practice provided a client is willing to pay their reasonable fee and the lawyer is not otherwise engaged. Many barristers and bar associations consider it to be a bulwark of the rule of law. ${ }^{1}$ The basic rationale for the cab rank rule is that everyone has a right to qualified legal representation. Yet the rule only has to be stated to falsify the claim. The rule does not apply to solicitors and the rule only applies to barristers if a solicitor is retained first. At most therefore, it provides well off clients who can find and afford a solicitor willing to act for them with access to the barristers of their choice if they can also afford their fees. Put simply, the rule supposedly designed to guarantee legal representation only becomes operative when a person already has legal representation.

The value of the cab rank rule has been the subject of considerable debate in recent years. In 2013 the Legal Services Board in England published research questioning the relevance of the rule to the modern legal services market. ${ }^{2}$ That research, in turn, sparked

\footnotetext{
${ }^{1}$ R Deech, 'The Legal Profession—Regulating for Independence' Gresham College, 9 May 2012. Baroness Deech is Chair of the Bar Standards Board; M Sloss, 'Independence, Service and the Stuff of Legend' Victorian Bar News, September 2012, p 3. Melanie Sloss SC was Chair of the Bar Council at the time of the article; A Thornton, "The Professional Responsibility and Ethics of the English Bar" in R Cranston (ed), Legal Ethics and Professional Responsibility (Oxford, Clarendon Press, 1995) p 68.

${ }^{2}$ J Flood and M Hviid, 'The Cab Rank Rule: Its Meaning and Purpose in the New Legal Services Market' 2013 (A report for the Legal Services Board, available at https://research.legalservicesboard.org.uk/wpcontent/media/Cab-Rank-Rule_final-2013.pdf ) Note all URLS last accessed 15 April 2016.
} 
considerable opposition from the Bar who asserted that it still performed a limited but vital role in promoting access to justice. ${ }^{3}$

When assessing the contribution of the cab rank rule to promoting access to justice, one cannot overlook the broader structure and funding of the justice system. In both England and Australia there have been very substantial, repeated cuts to legal aid eligibility. ${ }^{4}$ This has contributed to an access to justice "gap" for many people who cannot afford a lawyer and are no longer entitled to legal aid. The Australian Productivity Commission referred to this segment of the population as the 'missing middle, ${ }^{5}$ while according to the Civil Justice Council, the missing middle represents the majority of the population in England \& Wales. ${ }^{6}$ The consequence is that fewer people are in a position to invoke the cab rank rule, and more people are denied access to justice altogether, or are forced to navigate the court system on their own which can increase costs and/or result in cases being wrongly decided. ${ }^{7}$

\footnotetext{
${ }^{3}$ McLaren et al, 'The Cab Rank Rule: A Fresh View' 28 February 2013 (A report for the Bar Standards Board, available at https://www.barstandardsboard.org.uk/media/1460590/bsb_cab_rank_rule_paper_28_2 13 v6 final_pdf ); S Kentridge, 'The Cab Rank Rule: A response to the report commissioned by the Legal Services Board' 4 March 2013, p 21 (Available at: www.barcouncil.org.uk/media/203452/sir_sydney_kentridge_crr_response.pdf)

${ }^{4}$ See, eg, O Bowcott and S Moss 'Legal aid cuts: 6 lawyers on why they will damage our justice system' The Guardian, 1 April 2014; D Neal SC 'The continuing crisis in our legal aid' Sydney Morning Herald, 18 May 2013.

${ }^{5}$ Productivity Commission, Access to Justice Arrangements: Overview (No 72, 5 September 2014) p 20.

${ }^{6}$ Civil Justice Council, 'Access to Justice for Litigants in Person' (November 2011) para [14] (Available at https://www.judiciary.gov.uk/wp-content/uploads/2014/05/report-on-access-to-justice-for-litigants-in-personnov2011.pdf)

${ }^{7}$ A 2014 report of the National Audit Office found that there was 30\% increase in litigants in person in family cases following legal aid cuts, which was estimated to cost the courts an additional $£ 3.4$ million: National Audit Office, Implementing Reforms to Civil Legal Aid HC 784, Session 2014-15, 20 November 2014, p 4.

According to the Australian Government, self-represented litigants make up around 35 percent of parties in final orders: Australian Government 'Response to Productivity Commission's report into access to justice arrangements' (29 April 2016) (Available at https://www.ag.gov.au/LegalSystem/Pages/response-to-report-intoaccess-to-justice-arrangements.aspx). Australian courts have collected limited information about selfrepresented litigants (E Richardson \& Ors, Self-Represented Litigants Gathering Useful Information Final Report, June 2012 (Australian Centre for Justice Innovation (ACJI) Monash University) pp 17-18) but some statistics are revealing. For example, the proportion of High Court applications filed by self-represented litigants increased from 25 percent in 1999-2000, to 67 percent in 2007-08: Annual Report of the High Court 2008-09, page 17.
} 
The paper addresses a number of questions. First, what is the purp ose of the cab rank rule and is it still needed? (Part I) Second, does the rule work, taking into account its scope and practical effects, both positive and negative? (Part II) Third, could the cab rank rule be reformed to better promote access to justice? (Part III) At the outset it is important set out some caveats about the limited evidence and research available on the cab rank rule.

Commentators have observed that there is a dearth of empirical data about how the cab rank rule operates in practice, its effects, and how often it is breached. ${ }^{8}$ As part of their research for the Legal Services Board, Flood and Hviid carried out interviews with 'key players in the field ${ }^{9}$ but critics have questioned both the sample size (15 people) and representativeness of the respondents. ${ }^{10}$ More evidence would be helpful, although there would be inherent limitations in any study seeking to ascertain whether people are complying with their professional obligations. Occasionally there are public controversies, where lawyers decline to act for someone on religious, ideological or economic grounds, including well known examples of discrimination from other jurisdictions that do, and do not, have a binding cab rank rule. ${ }^{11}$ There is also surprisingly little peer-reviewed academic scholarship dedicated to the cab rank rule specifically ${ }^{12}$, and most of the scholarship is in short pieces in practitioner oriented journals. ${ }^{13}$ Undoubtedly many practitioners views of the cab rank rule are formed from their only personal experiences, and one of examples set out in Part II of this paper is based on the author's own personal experience as a part time practitioner at the Victorian Bar, however that example was based on the standard application of the Victorian Bar's rules and

\footnotetext{
${ }^{8}$ See eg L Reed 'A Trickle Not a Flood' 27 January 2013. (Available at http://pinktape.co.uk/legal-news/atrickle-not-a-flood/); Flood and Hviid (n 2) p 29.

${ }^{9}$ Flood and Hviid (n 2) p 2. Interviewees were regulators, government officials, barristers, solicitors, and barristers' clerks.

${ }^{10}$ McLaren et al (n 3) p 34.

${ }^{11}$ See discussion to footnotes [34]-[36].

12 A point also made by Flood and Hviid in their literature review: (n 2) p 14.

13 See eg J Goldsmith, 'Long live the cab rank rule' (2015) 112(15) Law Society Gazette 8; J Robins, 'Pulling rank' (2015) 165 NLJ 22; J Campbell and J Carruthers 'A rank bad rule' (2008) 53(8) JLSS 9 I Miller 'The cab rank rule' (2006) Counsel p 16-18; A Watson Advocacy for the unpopular: the barrister's cabrank rule in England and Wales - past present and future? (1998) 162 J.P 476-480.
} 
policies so it is unlikely to be exceptional. ${ }^{14} \mathrm{We}$ also have the opinions of relevant regulators who have been critical of its limited scope ${ }^{15}$, or are critical of its effects on competition in the legal service market. ${ }^{16}$ Moreover, while the precise market effects of the cab rank rule may be a matter of speculation, a great deal can be extrapolated from the terms of the rule itself.

The paper argues that the principle behind the cab rank rule is fundamentally sound given that legal representation should be available to all who need it in a society based on the rule of law. The main problem with the rule is that it does very little to prevent access on the grounds of discrimination, because the laudable non-discrimination principle that underpins it is so heavily qualified, and it does nothing to address the problem of increasingly unaffordable justice. Furthermore, to the limited extent the rule does apply, the rule unnecessarily distorts the legal services market, potentially increasing the costs of access to justice. Of course, a lack of access on economic grounds, and a lack of access on the grounds of identity or ideological discrimination have different causes, and the cab rank rule has only ever sought to address the latter problem not the former. Nonetheless, the principle of equality before the law does not distinguish between the reasons why access to court may be denied. And it is this equality principle from which the cab rank rule is derived. Accordingly, there is scope to "reboot" the cab rank rule as a compartmentalized universal service obligation on all legal service providers. This would, for the first time, guarantee representation the unpopular and also help bridge the access to justice gap experienced by the the poor, whilst minimizing unnecessary distortions to the legal services market.

\footnotetext{
${ }^{14}$ See the text to footnotes [54]-[61].

${ }^{15}$ Legal Services Board 'Legal Services Board does not want the 'cab rank' rule abolished, but to understand its limitations' The Lawyer (18 February 2013); C Passmore, 'Cab Rank on a ride to nowhere' The Lawyer 18 February 2013. Passmore is strategy director for the Legal Services Board.

${ }^{16}$ Office of Fair Trading, Competition in the Professions (Report No 328, March 2001)
} 


\section{Part I - What is the Cab Rank Rule's Purpose?}

An assessment of the value of any rule must begin by considering its purpose. Over the centuries, a number of rationales can and have been put forward for the cab rank rule including protecting the independence of the lawyer, respecting a client's autonomy to choose their own lawyer, preventing discrimination in legal services, protecting the right to a fair trial and/or protecting the universal right to legal assistance. A 2013 paper by barristers at Fountain Court Chambers, prepared for the Bar Standards Board, argues that its value is that 'everyone is able to get $\boldsymbol{a}$ lawyer', and more specifically, 'the lawyer of their choice.' ${ }^{17}$ The first claim overlooks the fact that the rule is dependent upon payment of a proper fee, however the second claim is true for clients who can afford the barrister of their choice. This raises a critical question that is rarely examined: should choice of lawyer be a right?

The right to choose one's lawyer could be intended to promote autonomy, but this cannot be a complete justification because protecting the client's autonomy necessarily limits the autonomy of the lawyer. ${ }^{18}$ Accordingly, there must be some value in protecting the client's choice of lawyer as a participant in the legal system. One reason might be that it provides a guarantee of legal representation that is independent of the state: you are entitled to choose your own lawyer rather than have one forced upon you by the institution that may even be your legal opponent. However this is a rather simplistic notion of independence given that the state's direct involvement in the justice system is necessary at many levels. State funding is needed if indigent litigants are to obtain legal representation through legal aid, which can be provided by government employed lawyers. There is no right to choose one's own lawyer at the state's expense. The European Court of Human Rights has also affirmed that the practice, common in European jurisdictions, where the state appoints a lawyer to represent a criminal

\footnotetext{
${ }^{17}$ McLaren et al (n 3) p 6 (emphasis in the original)

${ }^{18}$ M Quinlivan, 'The cab rank rule: a reappraisal of the duty to accept clients.' (1998) 28 Victoria University Wellington Law Review 113, 121.
} 
defendant, even against their will, is compatible with the right to fair trial under Art 6(3). Art $6(3)(c)$ guarantees that "everyone charged with a criminal offence has the right to defend himself in person or through legal assistance of his own choosing or, if he has not sufficient means to pay for legal assistance, to be given it free when the interests of justice so require.' ${ }^{19}$ According to the ECtHR, Art 6 is a purposive right and, read as a whole, 'guarantee[s] the right of an accused to participate effectively in a criminal trial ${ }^{20}$ (Emphasis added). Effective participation does not entail an unfettered right to choose one's legal team, given there is also a public interest in ensuring all trials are conducted both fairly and efficiently.

A slightly different justification for the cab rank rule, but which is also linked to maintaining a lawyer's independence, was outlined by Lord Neuberger, President of the UK Supreme Court, in 2013. He stated:

The requirement that a properly qualified advocate cannot refuse instructions presented on the basis of a reasonable fee to represent an individual in court is the means by which we guarantee robust and independent representation for all, even those accused of the most heinous crimes. It protects the lawyer from adverse influence, from public opinion, from improper pressure from the media or the State itself. ${ }^{21}$

Lord Neuberger appears to suggest that the cab rank rule protects lawyers' independence not by guaranteeing clients free choice but rather by limiting lawyers' autonomy. The rule protects lawyers who take on unpopular cases from public and governmental pressure for their "decision" to do so, because, in the words of Schwarz, it "insulates [the lawyer] from personal moral responsibility' of associating or dissociating oneself from the client's cause. ${ }^{22}$ If this is the case, there must be some doubt as to whether the rule is necessary, as opposed to formal recognition of the professional ideal that underpins it: i.e. lawyers are cogs in the

\footnotetext{
${ }^{19}$ Croissant v Germany (1993) 16 EHRR 135 (ECtHR); Lagerblom v Sweden Application No 26891/95 (ECtHR); Mayzit v Russia (2006) 43 EHRR 38 (ECtHR).

${ }^{20}$ Lagerblom $v$ Sweden (n 9) [49].

${ }^{21}$ Lord Neuberger, 'Tomorrow's Lawyers Today - Today's Lawyers Tomorrow' ('80' Club Association of Liberal Lawyers, 19 February 2013) (Available at https://www.supremecourt.uk/news/speeches.html\#2013 ). ${ }^{22}$ M Schwartz 'The Zeal of the Civil Advocate' in D Luban (ed) The Good Lawyer: Lawyers' Roles and Lawyers' Ethics (Rowman \& Allanheld, New Jersey 1984) 121.
} 
justice machine and justice requires that legal representation is available to all. ${ }^{23} \mathrm{~A}$ curious argument put forward by the barristers at Fountain Court Chambers in defence of the rule is that it helps lawyers answer the question put to them at social outings: 'would you represent a murderer? ${ }^{24}$ Presumably a lawyer who is not bound by the rule, including solicitors or American or Canadian lawyers, ${ }^{25}$ are not asked to leave their social functions if they explain they are servants in the administration of justice. Explaining the lawyer's purpose arguably performs a more educative role than simply saying "I have no choice; I am bound to take the case by professional rules."

The most promising rationale for the cab rank rule is that a right to choose one's own lawyer protects litigants against discrimination. The law does not accept discrimination based on race, sex or sexual orientation, amongst other things, so why would it accept legal service providers discriminating based on the identity of the client, their cause, or what they are accused of doing? Equally importantly, the rule prevents discrimination in a context where it could have serious deleterious effects. Were lawyers free to choose their clients based on the merits of their case, a decision to decline to act could be construed as a judgement that the their claim or defence is hopeless, making it harder for them to get a fair trial before the actual fact finder. When Thomas Esrkine agreed to represent Tom Paine in his trial for treason for writing The Rights of Man, he famously stated:

If the advocate refuses to defend, from what he may think of the charge or the defence, he assumes the character of the judge; nay, he assumes it before the hour of judgement; and in proportion to his rank and reputation puts the heavy influence of perhaps a mistaken opinion into the scale against the accused... ${ }^{26}$

\footnotetext{
${ }^{23}$ Sir Gordon Samuel advocated this approach when, as NSW Governor, he delivered the 1998 Sir Ninian Stephen Lecture: 'No more cabs on the rank? Some reflections about the future of legal practice' (1998) 3 Newcastle Law Review 1.

${ }^{24}$ McLaren et al (n 3) p 6.

${ }^{25}$ In the US and Canada the rule is a professional ideal: American Bar Association Model Rules of Professional Conduct 1983 - Rule 1.2(b) and Commentary (b); Federation of Law Societies of Canada Model Code of Professional Conduct - Rule 4.1-1 (provides a right to decline representation, but states it should be exercised prudently if it would make it difficult for a person to obtain legal assistance.)

${ }^{26} R v$. Paine (1792) 22 State Trials 357, 412.
} 
The risk of tainting juries in this way might even be greater in the $21^{\text {st }}$ century, where refusals to act could be easily disseminated through the internet and social media. Nor can this taint be ruled out altogether in judge only trials: the relationship between judges and lawyers remains close $\mathrm{e}^{27}$ and there is always a (small) risk that the professional judgment of the lawyer might subconsciously influence the decision making of the judge. The cab rank rule avoids this taint because it prevents lawyers from publicly declaring that they declined to represent a person because they thought their case was hopeless.

The value of the non-discrimination principle underpinning the cab rank rule is acknowledged by all, even its critics. Flood and Hviid, for example, have argued the rule should be translated into a universal requirement against discrimination on grounds of race, sex, sexual orientation etcetera, as well as the nature of the case. ${ }^{28}$ If the non-discrimination principle provides a sound justification for the cab rank rule, in theory the rule should apply to all legal service providers. Yet the overwhelming majority of legal service providers are not bound by the rule and are free to discriminate in their choice of clients on any grounds not covered by anti-discrimination law. Many solicitor firms discriminate both in relation to the areas of their practices and the types of clients they represent. Their motive is rarely to deny assistance to particular persons, but rather a desire to provide better quality legal services to a particular category of client. An obvious example is the capital/labour split: some law firms specialise in representing business clients while others focus on trade unions and their members. The notion that some lawyers are entitled to discriminate based on a client's identity but others are not, arguably defeats the purpose of an-anti discrimination law; it certainly defeats the right to choose one's own lawyer.

From a theoretical perspective, it is doubtful whether the non-discrimination principle underpinning the cab rank rule should be interpreted as a (qualified) right to choose one's

\footnotetext{
${ }^{27}$ Taylor v Lawrence [2002] EWCA Civ 90; [2003] QB 528 at [61], [73].

${ }^{28} \mathrm{~J}$ Flood and M Hviid (n 2) p 39.
} 
own barrister as opposed to a universal entitlement to legal assistance. The answer to this question, to some extent, depends on whether there is something intrinsically valuable in the non-discrimination principle, or whether it is a means of securing access to justice for those who might otherwise be denied it? If securing access is the ultimate goal, this would be compatible with specialisation, and even a degree of discrimination, by lawyers, provided the legal profession as a whole is able to provide legal representation to all who need it. ${ }^{29}$ If the answer to the famous (paraphrased) question 'If not me, who will represent this person?' is that the lawyer across the road will happily do so, the question loses much of its moral force.

An alternative view is that protecting the choice of the prospective client as to their preferred lawyer in itself protects the dignity of the prospective client. ${ }^{30}$ If this choice rationale is the correct rationale for the cab rank rule, it is instructive to compare it with the main features of discrimination law. A key tenet of discrimination law is that people should not be discriminated against on grounds that have the "potential to impair the fundamental dignity of persons as human beings. ${ }^{31}$ Undoubtedly, the cab rank rule overlaps with discrimination laws that protect the choices of individuals in their day to day lives from discrimination based on their identity, whether it be the choice of which hotel to stay in, ${ }^{32}$ or where to buy a wedding cake from, ${ }^{33}$ or which lawyer to represent them.

\footnotetext{
${ }^{29}$ Advocates of this approach argue it ensures access for all whilst protecting lawyers' moral autonomy. See eg M Quinlivan, 'The cab rank rule: a reappraisal of the duty to accept clients.' (1998) 28 Victoria University Wellington Law Review 113; B Raymond, 'The profession's duty to provide; a solicitor's right to choose' (1990) 140 New Law Journal 285.

${ }^{30}$ Most commentators agree that the protection of human dignity is a central aim of human rights generally, even though its meaning is difficult to pin down: A McColgan, Discrimination, Equality and the Law (Hart 2014) pp 23-24 citing D Feldman 'Human Dignity as a Legal Value: Part 1' (1999) Public Law 682. 31 See, for example, Harksen v Lane NO 19981 SA 300 (CC) (South Africa Constitutional Court); Vrien v Alberta [1998] 1 SCR 493. This is reflected in the 'characteristics' that receive protection under the Equality Act 2010, section 4: Race, Religion, or Belief, Gender reassignment, Sexual orientation, Marriage and Civil Partnership, Age, Sex, Pregnancy and Maternity and Disability. In Australia, discrimination law is covered by different pieces of legislation, at both Federal and State level, including the Age Discrimination Act 2004 (Cth), Australian Human Rights Commission Act 1986 (Cth), Disability Discrimination Act 1992 (Cth), Racial Discrimination Act 1975 (Cth) and Sex Discrimination Act 1984 (Cth).

${ }^{32}$ Constantine v Imperial Hotels Ltd [1944[ KB 693.

${ }^{33}$ Lee v Ashers Baking Co Ltd \& Ors [2015] NICty 2. In this case the defendants stated that they were willing to serve the customer, but not prepare a wedding cake with a slogan that supported gay marriage.
} 
The cab rank rule goes further by extending the non-discrimination principle to all persons, natural and legal, and all conduct whether or not it is connected with a person's identity. The potential adverse consequences of this extension are examined in part II. For present purposes, it is enough to observe it is the need to guarantee justice, rather than choice which is the usual reason given for the non-discrimination principle underlying the cab rank rule (which predates most discrimination law) both historically and even today.

\section{A. Is the rule needed?}

In a society based on the rule of law no serious commentator doubts the value of preventing discrimination against people who require legal representation in court. Some commentators, however, question whether a cab rank rule is really needed to prevent discrimination. Flood and Hviid observe that jurisdictions that do not have a binding rule, like the United States and Canada, appear to function perfectly well without it. They argue that there are sufficient professional and financial incentives to agree to act for people accused of even heinous crimes, or of being immoral. ${ }^{34}$

It is probably correct to say that the market will, in most cases, ensure a 'champion' comes forward to represent an unpopular litigant. Nonetheless, one cannot rule out the possibility of discrimination in the absence of a binding rule. The legal systems of the U.S and Canada do function well but that does not mean that some lawyers shun prospective clients for whatever reason, and there have been some high profile cases of ideological discrimination. ${ }^{35}$ Even in England, there are some reported cases of non-compliance with the cab rank rule. In one relatively recent case a Christian lawyer was reprimanded for declining a brief from a client seeking to use his homosexual relationship as grounds for being able to

\footnotetext{
${ }^{34}$ Flood and Hviid (n 2) p 31-32.

${ }^{35}$ In 'Long live the cab rank rule' (n 11) Goldsmith cites the example of leading U.S law firms refusing to represent parties opposing same sex marriage in their legal challenges to laws recognizing same.
} 
remain in the country. ${ }^{36}$ In less developed legal systems, discrimination and even collective discrimination by the profession is not uncommon. The experience in India, where barristers passed resolutions not to act for persons accused of rape or terror offenses, demonstrates that lawyers can be susceptible to societal and collective pressure to decline to represent persons who might even have a constitutional right to legal representation. ${ }^{37}$

Accordingly, it is difficult to resist the conclusion that some form of cab-rank rule is needed as a bulwark of the rule of law. This conclusion is strengthened if the cab rank rule is reframed not just as a principle of discrimination against those with the capacity to pay, but as a means of helping secure legal assistance for all those who need it regardless of the capacity to pay. In practice, in the context of substantial cuts to legal aid, the most common form of discrimination in access to justice is economic, and the group who are denied access on this ground represents a major part of the population. While governments are not indifferent to the costs of reduced access to justice, this has not altered the policy preference of shifting the burden of funding justice from the public to the private sector. In a speech setting out the Conservative Government's priorities for the English justice system, the Lord Chancellor called on the profession to do more in delivering access to justice for ordinary people. ${ }^{38}$ Pro bono work and contingency or conditional fees can help fill the gap of unmet legal need, but not eliminate it. Pro bono work naturally focuses on causes that the lawyer deems 'worthy'39, while contingency agreements work only for civil damages claims and

\footnotetext{
${ }^{36}$ J Mills, 'Barrister who refused to represent gay client reprimanded', Daily Mail, 26 July 2006, http://www.dailymail.co.uk/news/article-397625/Barrister-refused-represent-gay-client-reprimanded.html. ${ }^{37}$ One such resolution was adopted following the gang rape and death of an Indian student on a Delhi bus in December 2012, which led to massive public protests: The Indian Express, 3 January 2013. (Available at http://www.indianexpress.com/news/saket-bar-members-resolve-not-to-represent-rape-accused/1053655/ ). The resolution had been passed notwithstanding the Indian Supreme Court had earlier ruled that such practices were unconstitutional: A S Mohammed Rafi v State of Tamil Nadu Rep by Home Dept \& Ors [2010] INSC 1060 [32]. ${ }^{38}$ Lord Chancellor 'What does a one nation justice policy look like?' (Speech to the Legatum Institute, 23 June 2015) (Available at https://www.gov.uk/government/speeches/what-does-a-one-nation-justice-policy-look-like). ${ }^{39}$ The Productivity Commission found that the bulk of pro bono work in Australia is undertaken for not-forprofit organisations rather than for disadvantaged Australians directly. Moreover, the total level of pro bono services is relatively modest: less than 1 per cent of the entire legal market: Productivity Commission (n 5), p 32.
} 
naturally focuses on claims of high merit and potentially high value. ${ }^{40}$ The poor litigant whose cause is unpopular, and who does not have a claim that sounds in substantial damages, is at present entirely dependent on the state to provide them with legal representation, and that support is declining. In Part III, the paper examines whether it would be possible in practice to redefine the cab rank rule as a limited professional obligation to provide access to justice for all, including those with limited or no capacity to pay.

\section{Part II - Does the Rule Work?}

Assessing the efficacy of the cab rank rule requires consideration of a number of inter-related factors. These include the scope or reach of the rule, including its relationship with other professional rules regulating who lawyers can and cannot represent; whether the rule has any unintended effects on the administration of justice, including on persons who are not in a position to invoke it and the legal services market generally; and the degree of compliance with the rule.

\section{A. Limited Scope of the Cab Rank Rule}

Critics of the rule are quick to point out that the cab rank rule is limited to a small number of legal professionals, who are bound to follow the rule in limited circumstances. Here the English rule will be used as the example. ${ }^{41}$ The English Bar Standard's Board Code of Conduct, Rule C29, entitled 'The Cab rank rule', provides:

\footnotetext{
${ }^{40}$ Productivity Commission, Access to Justice Arrangements: Volume 2 (No 72, 5 September 2014) pp 617621.

${ }^{41}$ For the rule in NSW and Victoria, which is similar, see The Legal Profession Uniform Conduct (Barristers) Rules 2015, rule 17: A barrister must accept a brief from a solicitor to appear before a court in a field in which the barrister practises or professes to practise if: (a) the brief is within the barrister's capacity, skill and experience, (b) the barrister would be available to work as a barrister when the brief would require the barrister to appear or to prepare, and the barrister is not already committed to other professional or personal engagements which may, as a real possibility, prevent the barrister from being able to advance a client's interests to the best
} 
If you receive instructions from a professional client, and you are: a self-employed barrister instructed by a professional client and the instructions are appropriate taking into account the experience, seniority and/or field of practice of yourself you must, subject to Rule C30 below, accept the instructions addressed specifically to you, irrespective of:

a) the identity of the client;

b) the nature of the case to which the instructions relate;

c) whether the client is paying privately or is publicly funded; and

d) any belief or opinion which you may have formed as to the character, reputation, cause, conduct, guilt or innocence of the client.

According to statistics from the English Bar Standards Board, in 2014 there were 12,709 selfemployed barristers out of a total of 15,716 practising barristers. At the same time there were 130,382 solicitors with practising certificates. ${ }^{42}$ The reach of cab rank rule is small indeed. Even when it notionally applies, there are numerous exceptions. Rule C 30 of the code states it does not apply, inter alia, where the barrister is not available, the barrister is not offered a proper fee taking into account their experience, the length and complexity of the case, the professional client does not accept liability for the barrister's fees or is a credit risk, the client is seeking to engage a QC without a junior barrister and the QC thinks it is in the client's best interest to retain a junior barrister, or the client is seeking to retain the barrister directly. ${ }^{43}$ The exception for direct access (also known as public access) clients was criticised by the England \& Wales Legal Services Board when it approved rule changes allowing the extension of direct access work to a broader range of cases. The Board observed that the exception undermined the access to justice arguments on which both the cab-rank rule and direct access rules are based. ${ }^{44}$ Clients who are unfortunate enough to retain a solicitor on a

of the barrister's skill and diligence, (c) the fee offered on the brief is acceptable to the barrister, and (d) the barrister is not obliged or permitted to refuse the brief under rule 101, 103, 104 or 105.

${ }^{42}$ Statistics can be found respectively at https://www.barstandardsboard.org.uk/media-centre/research-andstatistics/statistics/practising-barrister-statistics/ and http://www.lawsociety.org.uk/support-services/researchtrends/annual-statistical-report-2014/.

${ }^{43}$ The exceptions in Australia are also similar: see The Legal Profession Uniform Conduct (Barristers) Rules 2015, rules 21, 105 .

${ }^{44}$ LSB Decision Notice 27 March 2013 'The Bar Standards Board's rules change application for the approval of revised rules for its Public Access Scheme and removal of the 'Media Comment' rule from its Code of Conduct' p 4. 
black list of defaulting solicitors - for failing to pay barristers' fees - are also not entitled to invoke the rule. ${ }^{45}$

From the above description of the rule, it is clear that its scope is largely a legacy of a time when the role of barristers and solicitors was strictly demarcated both formally and in practice. Yet even according to historical practice, the rule had an obvious flaw. Because adequate representation in court could be delivered only by a barrister who was formally instructed by a solicitor, if the rule was intended to prevent discrimination, it had to apply to solicitors as well. Given the inclination to judge the conduct of prospective clients, or avoid being associated with unpopular clients, are very human instincts, it is difficult to fathom why barristers but not solicitors might behave in this way, absent a binding rule.

The effect of the cab rank is that it does secure for clients, who have already retained a solicitor, the barrister of their choice if they can pay their reasonable fee, but it does not guarantee legal representation for anyone, popular or unpopular, rich or poor. All of the 'loathsome' people who have invoked the cab rank rule in England and Australia have done so only because they have first found a solicitor willing to represent them without compulsion. In Arthur Hall v Simons Lord Hoffmann took up this point when observing that non-compliance the rule would not deny a person legal representation. ${ }^{46}$

\section{B. Unintended Consequences of the Rule - Potential Market Distorting Effects}

The limited scope of the cab rank rule arguably reflects an (implicit) acknowledgement that to apply it more broadly would impose substantial costs on both lawyers and clients. A universal, fee dependent, non-discrimination rule has the potential to unnecessarily distort the legal services market.

\footnotetext{
${ }^{45}$ C Passmore, 'Cab Rank on a Ride to Nowhere' The Lawyer 18 February 2013. Passmore is strategy director for the Legal Services Board.

${ }^{46}$ Arthur JS Hall v Simons [2002] 1 AC 615, 696-697 (HL). See also M Zander, 'The myth of the cab rank' (1990) 140 New Law Journal 558.
} 
In relation to the structure of the legal services market, if the cab rank rule were truly universal in scope it would place substantial impediments on specialisation and therefore innovation in the legal services market. The absence of a cab rank rule allows solicitors, including traditional and new forms of legal practice - such as multi-disciplinary partnerships, alternative business structures and publicly listed law firms - to specialise both in subject matter and type of client they choose to represent. A well-known report prepared for the Office of Fair Trading into the Liberal Professions in 2001 concluded that the cab rank rule limited the development of new business forms such as partnerships because barristers would need to consider the interests and views of their partners before taking on a case. ${ }^{47}$ Flood and Hviid have argued that abandoning the rule would make market signals clearer and more direct, allowing lawyers to more thoroughly inform clients about the services they offer. $^{48}$

A second potential adverse impact of the cab rank rule is more speculative, and would be difficult to test empirically, but it is worth considering, is the potential for the can rank rule to distort price negotiations. A 'free' legal services market will not necessarily produce a different result to that generated by the cab rank rule in particular cases, but it could. Firstly, we know that barristers cannot increase their fees to represent certain clients or substitute more profitable or attractive briefs for the first one to come along. ${ }^{49}$ While that may be beneficial to some clients, it can also disadvantage others who might otherwise be able to negotiate lower fees were barristers were free to adjust their fees for different clients. Business models built around offering different price points for different types of consumers is not uncommon. Putting commercial considerations to one side, there is also a possibility

\footnotetext{
${ }^{47}$ Office of Fair Trading, Competition in the Professions (Report No 328, March 2001) p 81.

${ }^{48}$ Flood and Hviid (n 2) p 39. A degree of client driven specialisation is still possible because clients can choose to retain barristers who have represented similarly situated clients.

$49 \mathrm{G}$ Hanlon and J Jackson, Last Orders at the Bar? Competition, Choice and Justice for All-The Impact of Solicitor-Advocacy (1999) 19 Oxford Journal of Legal Studies 555, 556.
} 
that some lawyers would consider rejecting briefs for the purposes of taking more intellectually or emotionally rewarding legal work, even if less well paid.

In addition, the right to choose one's own barrister could, counter intuitively, reduce the bargaining leverage of the client in negotiating the barrister's fee. Hadfield has noted that the legal services market has a number of features that makes impossible the type of rational consumer behaviour that drives ordinary market competition. Consumers find it difficult to judge the quality of legal service providers because of their limited knowledge and experience of the legal system. The adversarial 'winner takes all' nature of the legal process means that marginal differences in the quality of lawyers can make all the difference in obtaining a favourable outcome. Because legal outcomes are uncertain, and the additional value of retaining the best or a better lawyer is real but difficult to measure, the only rational choice for the prospective client is to choose the lawyer that they consider to be the best at the highest price that they can afford.$^{50}$ Hadfield's analysis was concerned with the U.S legal services market where a cab rank principle is only a professional ideal. The question is whether a binding cab rank rule makes this lack of competitive market pressure worse? In theory, the knowledge that if you do not retain the best lawyer that you can afford straight away, your opponent has a right, not merely a chance, to retain them, adds to the incentives to pay the lawyer's nominated fee without negotiation. These incentives work to the advantage of senior and better lawyers as Flood and Hviid have argued. On the other hand, Flood and Hviid also suggest that the cab rank rule gives solicitors greater leverage in their negotiations with junior barristers, who have limited scope to increase their fees, and are obliged to accept a brief unless an exception to the rule applies. ${ }^{51}$

Another adverse effect of the cab rank rule, which receives relatively little attention in the literature, is its potential to exacerbate inequality of arms between litigants. Proponents of

\footnotetext{
${ }^{50}$ G Hadfield, 'The Price of Law: How the Market for Lawyers Distorts the Justice System" Michigan Law Review 98 (2000): 953, 975.

${ }^{51}$ Flood and Hviid, (n 2) p 20.
} 
the rule argue it helps promote equality of arms because the services of capable barristers remain available to all. Companies and government and repeat players cannot demand exclusivity from barristers, thereby denying others the best talent at the bar. The loathsome, the unpopular, or even the average 'nobody' is still able to secure the best legal representation, because the best lawyer in the field cannot decline their brief. ${ }^{52}$ This argument would make even a legal formalist blush. The best lawyer in the field may be notionally available to take a call from a homeless or unemployed person if the client is first able to find a solicitor willing to act for them (usually pro bono), but the payment of the barrister's reasonable fee will often be an impossible condition to meet. Moreover, research suggests that "repeat players" in litigation do better than "one shotters" suggesting that even if the best talent at the bar is available to all under the cab rank rule in theory, in practice it is not available to all, or "repeat players" are better able to use the legal resources available to them. ${ }^{53}$ Yet the fact that the cab rank rule cannot secure genuine equality between the parties is not a valid argument against it. No legal rule, whether it be the cab rank rule, legal aid, or the rules of the court, can eliminate from the court room the effects of any inequality that exist beyond it. It is unaffordable and technically impossible to devise a system that ensures that each party's lawyer/s are of the same standard and experience of the lawyer/s on the other side. This egalitarian objective is also not consistent with the legal definition of 'equality of arms' which is more modest in its ambition. Legal equality of arms requires that each party be given an opportunity to adequately prepare and present their case in accordance with procedural rules that do not place the party at a substantial disadvantage vis-à-vis their

\footnotetext{
${ }^{52}$ Mclaren et al (n 3) p 2-3, 7.

${ }^{53}$ Flood and Hviid (n 2) citing C Henretty, Haves and Have-Nots before the Law Lords (2014) 62 Political Studies 686-697. The proposition holds true in jurisdictions not covered by a binding cab rank rule as well: M Galanter Why the "Haves" Come out Ahead: Speculations on the Limits of Legal Change (1974) 9 Law \& Society Review pp. 95-160.
} 
opponent. ${ }^{54}$ It is trite, however, that if one side has retained Cicero to represent them, the other side is not entitled to their own Cicero in order for there to be a fair trial. At most the cab rank rule can aspire to securing competent legal representation to those who would otherwise be denied any representation: 'competent' meaning someone duly qualified and with the appropriate experience to adequately represent their client.

In its current form the cab rank rule could exacerbate inequality of arms, properly defined, in favour of unpopular wealthy litigants. This is because the skills of the most capable barristers can be automatically secured by clients with substantial resources, and then deployed against everyone else whether their cause is popular or not. Those persons who cannot invoke the rule can find themselves without legal representation or out-lawyered, because under the rule, a client can hire not only their barrister of choice, but as many barristers as they wish. Put simply, there are no 'proportionality' limits on the application of the cab rank rule.

The capacity of the cab rank rule to worsen inequality of arms is particularly evident when its effects are combined with other professional rules that regulate when lawyers can and cannot act for a client. An illustrative example comes from tobacco litigation in Australia. The largest tobacco company in Australia, British American Tobacco Australia (hereafter 'BAT') is always represented by some of Australia's best and most expensive barristers and law firms This includes Allan Myers AC QC, who has represented BAT in cases of alleged document destruction, and was lead counsel BAT's challenge to the government's tobacco plain packaging laws. The latter work included an appearance in the Australian Senate to make representations on behalf of BAT. ${ }^{55}$ When public health advocates

\footnotetext{
${ }^{54}$ See eg Dombo Beheer BV v Netherlands (1994) 18 EHRR 213, ECtHR; Mantovanelli v France, (1996) 24 EHRR 370 ECtHR; Van de Hurk v Netherlands (1994) 18 EHRR 481, ECtHR; W.J. v Austria (1999) 27 EHRR CD 83 ECtHR.

${ }^{55}$ Prior to his appearance alongside the CEO of BAT, the company released a statement saying 'Allan Myers is one of Australia's leading lawyers...We are hopeful the [Senate] committee will listen to his considered opinion about these draft laws which, in our opinion, are simply bad law': 'Big Tobacco Huffs and Puffs' Sydney
} 
questioned Mr Myers work for BAT, and suggested it may create a conflict of interest with his work with cancer charities ${ }^{56}$ the Victorian Barristers association came to his defence by arguing that it was required by the cab rank rule. ${ }^{57}$ By contrast, the case of Laurie $v$ BAT demonstrates that those seeking to bring claims against BAT have struggled to find legal representation. Mr Laurie was a former smoker and lung cancer victim who passed away in 2006. He brought a claim for damages against BAT which was continued after his death by his widow. Because the Lauries were pensioners on social security they could never invoke the cab rank rule. They were represented by several different law firms over 7 years on a conditional fee basis. After lengthy interlocutory proceedings, including a trip to the High Court ${ }^{58}$ the Lauries literally ran out of law firms willing to represent them. A practicing Victorian barrister offered to represent them as direct access clients on a pro bono basis. ${ }^{59}$ However such representation required approval from the Victorian Bar Society's Ethics Committee, because the Bar Society maintained restrictions on direct access clients, notwithstanding that the relevant legislation provided that a lawyer may accept instructions from a client whether or not the client has retained any other lawyer. ${ }^{60}$ The professional rules prohibited barristers taking on direct access clients for matters in most courts in Victoria and Federally without permission from the Ethics Committee. ${ }^{61}$ The Committee had issued guidance stating it would only grant dispensation from this rule in 'exceptional circumstances', and the inability of a prospective client to afford a solicitor does not qualify

\footnotetext{
Morning Herald, 13 September 2011. (Available at: http://www.smh.com.au/national/big-tobacco-huffs-andpuffs-20110912-1k6bc.html)

56 J Stark, 'Peter Mac Denies Tobacco Conflict' Sydney Morning Herald, 2 September 2012 (Available at http://www.smh.com.au/national/peter-mac-denies-tobacco-conflict-20120901-257h2.html)

${ }^{57}$ M Sloss SC 'Independence, Service and the Stuff of Legend' Victorian Bar News, September 2012, p 3. Melanie Sloss was Chair of the Bar Council at the time of the article.

${ }^{58}$ British American Tobacco Australia Services Ltd v Laurie [2011] HCA 2, (2011) 242 CLR 283.

59 The author was the barrister concerned.

${ }^{60}$ The Legal Profession Act 2004 (Vic) s 3.2.3 (The Act has been repealed and replaced by the Legal Profession Uniform Law)

${ }^{61}$ Victorian Barristers Association Rules of Conduct (2009) rule171: Appearances on behalf of direct access clients were prohibited in any legal proceeding in the High Court, the Federal Court, the Family Court, the Supreme Court of Victoria, the County Court of Victoria (except in legally aided criminal matters), or in any civil proceeding in the Magistrates' Courts of Victoria or the Federal Magistrates Court, without the written permission of the Victorian Bar's Ethics Committee.
} 
as an exceptional circumstance. ${ }^{62}$ The Ethics Committee refused the Laurie family permission to brief the barrister directly on the grounds that the case was sufficiently complex that they also required a solicitor to instruct counsel in court. Unable to find a solicitor willing to represent them, the Bar ethics committee effectively denied the Lauries access to any legal representation, and they were forced to drop the case. Victoria now operates under the Legal Profession Uniform Law, which does not replicate the blanket prohibition on direct access work in most courts, but the new rules might not have produced a different outcome. The Legal Profession Uniform Conduct (Barristers) Rules 2015 still contain restrictions on the type of legal work barristers can perform when acting for a client directly, essentially with the purpose of preventing them from acting as both solicitor and barrister. ${ }^{63}$

\section{Does the Cab Rank Rule have any Effect?}

An obvious rejoinder to the argument that the cab rank rule distorts the legal services market, comes not from supporters of the cab rank rule but its critics: it applies only to a small number of legal service providers, and is subject to so many exceptions, that it is more in the nature of a professional ideal than a binding rule. Thus the effect of the rule on the legal services market, whether positive or negative, is likely to be small or negligible. These reservations are compounded by the difficulties of enforcing the rule.

In Arthur Hall v Simons Lord Steyn suggested that the practical impact of the rule 'is not great' because it can be easily circumvented. Whilst acknowledging it was 'a valuable professional rule', he noted that 'in real life a barrister has a clerk, whose enthusiasm for unwanted briefs may not be great, and he is free to raise the fee within limits. ${ }^{64}$ For lawyers disinclined to represent someone, there are always legitimate reasons that can be advanced

\footnotetext{
${ }^{62}$ Bulletin No 2 of 2012 of the Victorian Bar's Ethics Committee.

${ }^{63}$ Legal Profession Uniform Conduct (Barristers) Rules 2015, rules 12-13.

${ }^{64}$ Arthur JS Hall v. Simons [2002] 1 A.C. 615, 678. See also Lord Hope at p 714. See also P Tague, Effective Advocacy for the Criminal Defendant: The Barrister vs the Lawyer (1996) p 129.
} 
for declining the brief, including a lack of time. Similarly, the fact that barristers do vary their fees depending on the complexity of the work, the amount of work involved, or the capacity of the client to pay, makes policing the rule extremely difficult. Flood \& Hviid questioned whether the rule was enforceable 'because all but the most egregious detraction from the rule will be unnoticed. ${ }^{65}$ Clients who suspect that they are being discriminated against will have difficulty proving their complaint.

While the precise market effects of the cab rank rule may be a matter of speculation, what can be said with confidence is the market would not operate in the same way without the rule, and its costs are borne by the legal service providers who are bound by it, and ultimately the clients and would be clients who cannot utilize it.

\section{Part III - Could the Cab Rank Rule be Reformed to Better Promote Access to Justice?}

Having examined the rationales for the cab rank rule, and its effects (or non-effects) in practice, in this part we consider ways of reframing the cab rank rule to better align it to its supporting rationale: to provide legal representation to all those who need it.

\section{A. The Cab Rank Rule Should Apply to all Legal Service Providers}

We find ourselves in the unsatisfactory position where lawyers recognize a universal service obligation which applies only to a small fraction of lawyers - self-employed barristers - and does not guarantee universal service to anyone, even those who can afford to pay for it. Confining the cab rank rule to self-employed barristers instructed by solicitors is anachronistic in light of reforms in both England and Australia that limit the demarcation between barristers and solicitors, allowing them to perform the same role and requiring them to meet the same standards. These reforms have included giving solicitors rights of audience

\footnotetext{
${ }^{65}$ Flood and Hviid,(n 2) p 2. This claim is disputed by McLaren et al. See text to (n 25).
} 
to enable them to do advocacy work in all courts, ${ }^{66}$ as well as loosening restrictions on barristers' practice, allowing them to represent clients directly ${ }^{67}$ and become employees (and partners) of law practices. ${ }^{68}$ Barristers associations maintain the value of a formal demarcation between the two branches, citing their commitment to the public interest as reflected in the cab rank rule, and their independence from the client, which serves both the administration of justice and the client's best interests. ${ }^{69}$ The difficulty with this claim is that the professional obligation of independence for barristers is indistinguishable from the professional obligation of independence for solicitors. The first three Principles of the Solicitors Regulation Authority Code of Conduct 2011 state: You must: 1. uphold the rule of law and the proper administration of justice; 2. act with integrity; and 3 not allow your independence to be compromised.

None of the distinctions between barristers and solicitors, whether formal or practical, are germane to the principle underpinning the cab rank rule or the need for such a rule. Either the cab rank rule can be justified for all qualified legal service providers or it cannot be justified for any provider. Barristers should be proud of their commitment to a universal service obligation as reflected in the cab rank rule, but to make the rule work, and to make its burden more equitable, it should apply to all legal service providers including solicitors. ${ }^{70}$

The major cost of extending the cab rank rule to all qualified legal service providers is that it might hamper the development of specialized legal practices that can offer improved and/or cheaper services to particular market segments. The only viable way of enshrining a universal service obligation covering all service providers whilst also allowing for specialization in legal services would be to compartmentalize a lawyer's universal service

\footnotetext{
${ }^{66}$ In England see Solicitors Regulation Authority, Higher Rights of Audience Regulations (2011), Regulation 2. Where the profession is formally fused, as in Australia, they already have such rights of audience.

${ }^{67}$ See text to (n 32) and (n 45).

${ }^{68}$ Legal Services Act 2007, section 189.

${ }^{69}$ See eg R Deech (n 1).

${ }^{70} \mathrm{Or}$ at least to all independent legal service providers, given salaried legal providers perform particular roles exclusively for their employer/client.
} 
obligation to a set number or percentage of their billable hours. How such a scheme might work is discussed further below. The point for present purposes is that in the current regulatory framework the rationale for applying the cab rank rule to self-employed barristers applies equally to all legal service providers, and regardless of the means by which they provide the service, whether directly to the public or as part of a legal team comprising both solicitors and barristers.

\section{B. The Cab Rank Should be Linked to the Need for Legal Representation}

It might seem obvious given the purpose of the cab rank rule, but the rule is not actually tied to a client's need for legal representation. This is for three reasons, two of which have already been mentioned. First the rule cannot be invoked unless a litigant has already obtained legal representation through a solicitor. Second, litigants with the means to invoke the rule can retain as many barristers as they like in the same case. A barrister cannot decline a brief on the grounds that adding another lawyer to the client's legal team would be disproportionate given the number of lawyers already representing them, or because the barrister's skills would be better utilized representing clients who have no legal representation at all or genuinely need the services of a barrister. A sensible modification to the rule, which would in no way prejudice the client's right to representation, would be to allow lawyers to reject instructions on proportionality grounds.

The third reason for the disconnect between the cab rank rule and the need for representation is that the rule applies to anyone who 'wants' representation. ${ }^{71}$ The idea is that it is not for a lawyer to judge the merits of their client's cause; they should act on their instructions and let the litigation process take its course. In Rondel v. Worsley Lord Pearce stated:

${ }^{71}$ McLaren et al (n 3) p 6 
It not infrequently happens that... those who have apparently hopeless cases turn out after a full and fair hearing to be in the right and it is a judge's (or jury's)solemn duty to find that out by a careful and unbiased investigation. This they simply cannot do if counsel do not (as at present) take on the less attractive task of advising and representing such persons however small their apparent merits. ${ }^{72}$

This statement is no longer correct if it implies that barristers are obliged to put forward hopeless arguments on behalf their clients. Lawyers are required to exercise independent judgment and 'should not argue hopeless points (and if their client insists, should refuse to do so)'. ${ }^{73}$ Moreover, as a practical reality, lawyers contemplating representing indigent litigants, either on a pro bono or conditional fee basis, invariably assess the merits of their prospective clients' cause. These informal gatekeeper mechanisms have been enshrined in some jurisdictions for all clients. For example, in Victoria the legal practitioner acting for a party must certify that each allegation of fact, denial of a fact, or non-admission of a fact, made in a statement of case $^{74}$ has a proper basis in light of the factual and legal material available. ${ }^{75}$ In England a number of court documents must be verified by a statement of truth, ${ }^{76}$ and while the statement must be made by the party, or the lawyer on their behalf, professional conduct rules state that lawyers must not be complicit in another person misleading the court. ${ }^{77}$

From an economic standpoint, the limited resources available to the civil justice system means that resources cannot be squandered on cases that have no reasonable prospects of success, or do not otherwise raise important issues of procedure. The court's summary judgment procedure exists to dispose of cases that do not require the investment of further resources to uncover more facts or develop more legal argument. ${ }^{78}$ On one view the summary judgment procedure performs the function that the client's lawyer ought to have

\footnotetext{
${ }^{72}$ Rondel v.Worsley [1969] 1 AC 191, 275 (HL).

${ }^{73}$ McLaren et al (n 3) p 56.

${ }^{74}$ Described in the Civil Procedure Act 2010 (Vic) as the 'first substantive document' in the civil proceeding: section 42.

75 ibid. See also, eg, Uniform Civil Procedure Rules 2005, r 14.23 (NSW).

${ }^{76}$ CPR 22

${ }^{77}$ Solicitors Regulation Authority, Code of Conduct 2011, O(5.2)

${ }^{78}$ A Zuckerman, On Civil Procedure ( $3^{\text {rd }}$ edn, Sweet \& Maxwell, 2013) [9.45]-[9.46].
} 
carried out in the first place. This is not always the case as some summary judgment decisions can be border line. The point of principle, however, is that the right of access to court relates to the protection of rights. There is no right to air one's grievances before a court if they do not sound in a legal claim or defence. If lawyers are officers of the court with an overriding duty to the administration of justice, it cannot be right that the requirement to act for anyone includes bringing or defending civil cases that have no reasonable prospects of success.

This suggested merits review is relevant to civil proceedings only. The law regarding the need for legal representation to defend criminal charges, even if one cannot afford to pay, is well established both in England and Australia and not limited to merits based analysis. ${ }^{79}$

\section{Rebooting the Cab Rank Rule as a Limited Universal Service Obligation}

Extending a cab rank rule to all legal service providers would be a major reform, and it is worth exploring in more detail whether such a rule could be made workable in practice. The primary aim is to develop a USO that can act as a supplement to state legal aid, and voluntary pro bono work, in securing legal representation for both the unpopular and the poor whenever the interests of justice require.

Two radical reforms, which extend well beyond the cab rank rule, but neatly capture the potential directions in travel in the access to justice debate, are to further de-regulate the legal services market to allow greater choice in legal service providers and funding arrangements, or to further regulate the litigation process including the cost of legal representation. Many of the reform proposals made by the Australian Productivity

\footnotetext{
79 The complexity of the case and the consequences for the defendant are key considerations: Benham $v$ UK (App no 19380/92) (1996) 22 EHRR 29; Ashworth and M Redmayne, The Criminal Process ( $4^{\text {th }}$ edn OUP 2010) p 34. In Australia there is no right to a lawyer at public expense, but the court has the power to stay a criminal proceeding if the lack of representation would result in unfair trial: Dietrich $v$ The Queen (1992) 177 CLR 292.
} 
Commission in its 2014 report could be categorized as targeted de-regulation ${ }^{80}$, while Australia already permits law firms to publicly incorporate. ${ }^{81}$ England allows third party litigation funding, and contingency fees subject to (much criticized) regulatory restrictions ${ }^{82}$, and through the Legal Services Act 2007 partially de-regulated the market, exempting the giving of legal advice from the list of 'reserved activities', and permitting the use of alternative business structures to deliver legal services (colloquially known as 'Tesco Law'). Alternatively, one could follow the approach of some civil law jurisdictions where legal representation is compulsory for all litigants and tariff systems are used to regulate legal costs, including maximum lawyer-client fees. ${ }^{83}$ It is beyond the scope of this paper to consider which direction of travel justice systems should head in. The reforms outlined here are designed to be compatible with the best features of a free market in legal services, whilst recognizing the crucial role that qualified legal representation plays in delivering access to justice. $^{84}$

Moving beyond the policy options in theory, one cannot ignore the political reality that governments of all persuasions in England and Australia appear committed to shrinking, or at least not substantially increasing, state support for the justice system. ${ }^{85}$ Accordingly, it

\footnotetext{
${ }^{80}$ Including the creation of limited legal practice licenses in family law and potentially other areas (Recommendation 7.5), allowing clients to purchase 'unbundled' legal services (Recommendation 19.1), and lifting the prohibition on contingency damages (Recommendation 18.1): Productivity Commission (n X), pp 3738.

${ }^{81}$ Although early experience has demonstrated that this involves substantial risk. Slater \& Gordon, the first firm in the world to go public, is now in severe financial difficulties: L Battersby, 'What happens when the ambulance chasers crash' Sydney Morning Herald, 5 March 2016 ( Available at http://www.smh.com.au/business/markets/slater-and-gordon-what-happens-when-the-ambulance-chasers-crash20160303-gn9kt8.html )

${ }^{82}$ Damages Based Regulations 2013, SI 2013/609; Lord Justice Jackson, 'Fixing and funding the costs of civil litigation' (2015) 34 CJQ 42.

${ }^{83}$ Italy is a notable example. The ECJ has rejected competition related challenges to the Italian rules, and even praised the Italian model: see e.g Commission v Italy (C-565/08) (European Court of Justice Grand Chamber, 29 March 2011) ECR 2011, I-02101 .

${ }^{84}$ A Zuckerman, 'No Justice Without Lawyers: The Myth of an Inquisitorial Solution' (2014) 33 CJQ 355;

R Assy, 'Can the Law Speak to its Subjects? The Limitations of Plain Language' (2011) 38 Journal of Law and Society 376.

${ }^{85}$ For theoretical arguments that the state has a duty to subsidise access to justice for the poor see, eg, E Cohn, 'Legal Aid for the Poor: A Study in Comparative Law and Legal Reform' (1943) 59 Law Quarterly Review 250, 256; D Luban, Lawyers and Justice: An Ethical Study (Princeton University Press, 1988) 243-8.
} 
seems both inevitable and desirable to structure the legal services market in such a way to as allow market forces to satisfy as much legal need as is possible. A free market for qualified legal representation would, contrary to the current cab rank rule, allow clients and service providers to choose each other, subject to discrimination law, and freely negotiate the cost and means of funding those services. Although a strong argument can be made that the cab rank rule has no substantial effects on the legal services market - positive or negative because it is so heavily qualified, confining the non-discrimination principle to the limits of general discrimination law, would ensure that there are no unnecessary restrictions on innovation and specialization of legal services.

This proposal is not based on a challenge to the non-discrimination rationale for the cab rank rule. Rather, it is a response to the technical question of how best to achieve this non-discrimination principle in practice, all be it at the cost of foregoing a qualified right to choose one's own advocate. A free market is an efficient means of satisfying demand which can be supplied profitably, and will always represent a vital part of any funding model for access to justice where public subsidy is falling. Were all legal service providers free to decline to act for particular clients, there would remain a risk that 'refusals' to act could prejudice the litigation process. This could be addressed by adapting confidentiality rules that prohibit barristers from media comment on pending cases to also prohibit disclosures of a refusal to act in pending cases. ${ }^{86}$

While a free market in qualified legal representation may be necessary to facilitate access to justice for all, it is hardly sufficient to achieve that objective. So how do we meet the demand for legal representation from persons who are not able to afford, or due to unpopularity would not be able to secure, private legal assistance? The central proposal put forward in this paper is to reboot the cab rank rule as a compartmentalized universal service

\footnotetext{
${ }^{86}$ The rules restricting media comment about the merits of current or potential proceedings could be amended for this purpose: see Legal Profession Uniform Conduct (Barristers) Rules 2015, rule 76.
} 
obligation for legal service providers, which would exist alongside the private market, and supplement legal aid. A compartmentalized USO would, for the first time, guarantee legalrepresentation to the unpopular, and in another 'first', be capable of bridging the access to justice gap experienced by the poor as well.

Each practice year all practising lawyers could be required to dedicate a small proportion of their total billed hours to representing people who are unable to secure legal assistance through the market. Each eligible litigant would be allocated the next available lawyer in the rank practising in the relevant field. It should be stressed that a compartmentalized USO is not necessarily the same thing as a compulsory pro bono scheme. Rather a small percentage of lawyer's practice would be fully regulated including the costs that can be charged to clients. This regulated public cab rank could also cover litigation funders, requiring them to pay a small percentage of their total annual revenue from litigation funding towards funding the public cab rank. However including litigation funders in the scheme would require the regulation, or licensing, of litigation funders which is not presently the case in either jurisdiction. ${ }^{87}$

A number of factors would be critical to the viability of any USO or regulated public cab rank. All USOs have some market distorting effects, so a balance must be struck between making the obligation broad enough to achieve its objectives, whilst making sure the burden on legal service providers, and the clients who pay private market rates (and ultimately pay for the USO), are not unduly onerous.

\section{i) Time required on the rank}

How much time each lawyer would have to dedicate to a public rank would, of course, be crucial to its success or failure. Factors to take into account include the level of unmet legal

\footnotetext{
${ }^{87}$ The Productivity Commission did recommend a licensing scheme for litigation funders in their report on access to justice arrangements: (n 5) Recommendation 18.2, p 61.
} 
need, the amount of public legal assistance private providers can be reasonably expected to provide and the need to ensure private legal practice is viable for providers and affordable for paying clients. While the system could be built around calculating a lawyer's (or firm's) USO as a small percentage of their total billable hours in the previous year, other criteria could also be used. To make the system more progressive, for example, the amount of time could be correlated to the amount of fees generated in previous year/s: i.e. the lower the fee income the fewer hours that a lawyer would need to serve on the rank.

While the rank would need to be mandatory for all legal service providers, it might be possible to give providers choices as to how to fulfil their obligation. Lawyers who did not wish to dedicate their labour to this public rank could, as an alternative, pay a fee based on a percentage of their total fees in the previous year, which would be used to fund the rank. Conversely lawyers who did pro bono work could claim credit for such work when their time spent on the cab rank was being calculated. The point to emphasize is the amount of time required on the rank could be small and would still have a significant effect on closing the access to justice gap. According to the Productivity Commission less than $1 \%$ of the legal market in Australia is dedicated to pro bono work. ${ }^{88}$

\section{ii) Costs, eligibility and administration}

Another key element in the design of the rank would be the level of costs that could be charged to the client. Legal costs would have to be regulated to reflect the fact that much unmet legal need is due to lack of financial resources, however it should not be assumed that legal work on the rank need be loss making. To make the system viable reasonable fees need to be levied to reflect the fact the lawyer is providing a 'no frills' service. Common law and

\footnotetext{
${ }^{88}$ Productivity Commission (n 5) p 32.
} 
especially civil law systems have considerable experience in setting fixed recoverable legal fees, for both pecuniary and non-pecuniary claims. The German system is arguably the best example, where court fees and legal costs are highly regulated ${ }^{89}$ In Germany recoverable legal fees are fixed and calculated as a modest percentage of the value of the claim. ${ }^{90}$ Although these tariffs are formally limited to recoverable costs, because court costs and recoverable costs are proportionate and predictable, Germany has a vibrant 'before the event' insurance market so that many German households have legal expenses insurance if they ever need to go to court. The insurance market is also a principal driver behind costs agreements that use the tariffs in the RVG even for a party's own legal costs. ${ }^{91}$ England has also introduced fixed fees for certain categories of case, including low value personal injury claims, ${ }^{92}$ and senior members of the judiciary including the Master of the Rolls, and Lord Justice Jackson, have advocated that fixed fees be expanded much further. ${ }^{93}$ The point for present purposes is not to advocate for any particular system of fixed costs, but simply to

\begin{tabular}{|c|c|c|}
\hline $\begin{array}{c}\text { Value of the claim is } \\
\text { up to } € \ldots\end{array}$ & $\ldots$ for each additional amount of $€ \ldots$ or part thereof & the total fee shall increase by $€ \ldots$ \\
\hline \begin{tabular}{|c|}
2,000 \\
\end{tabular} & 500 & 35 \\
\hline 10,000 & 1,000 & 51 \\
\hline 25,000 & 3,000 & 46 \\
\hline 50,000 & 5,000 & 75 \\
\hline 200,000 & 15,000 & 85 \\
\hline 500,000 & 30,000 & 120 \\
\hline $\begin{array}{l}\text { more than } \\
500,000\end{array}$ & 50,000 & 150 \\
\hline
\end{tabular}

For helpful summaries of the German system see G Wagner 'Litigation costs and their recovery: the German experience' (2009) 28 CJQ 367; R Jackson, Review of Civil Litigation Costs: Preliminary Report (May 2009) chapter 55.

${ }^{91}$ Ibid. Litigants remain free to negotiate different arrangements with their own lawyer if they so choose, although there are restrictions on the use of contingency fees. In 2007 the German Constitutional Court struck down a law providing an outright ban on contingency fees as incompatible with the right of access to court: BVerfG, 1 BvR 2576/04 vom 12.12.2006.

${ }^{92}$ CPR 45.

${ }^{93}$ Lord Dyson MR 'Magna Carta and Compensation Culture' (The High Sheriff's Law Lecture, 13 October 2015) (Available at https://www.judiciary.gov.uk/wp-content/uploads/2015/10/high-sheriffs-speech.pdf); R Jackson, 'Fixed Costs - The Time Has Come' (IPA Annual Lecture, 28 January 2016) (Available at https://www.judiciary.gov.uk/announcements/speech-by-lord-justice-jackson-fixed-costs-the-time-has-come/ ). 
recognize that systems of regulated fees are possible, already in place in different jurisdictions, and designed to strike a balance between affordable 'no frills' legal representation and economically viable legal practice. Moreover, under the system proposed here, the regulated fees would only apply to representation provided through the public cab rank, which would only be a small fraction of the lawyer's legal practice.

As with most legal aid schemes, client eligibility for the public cab rank would involve both a merits review and financial eligibility checks. Obviously, the more modest the scheme the tighter the eligibility criteria would need to be. Although the vision behind the proposal is that all cases should be eligible if meritorious (in the case of civil proceedings), or if the charges and potential penalties are significant (in the case of criminal proceedings), distributive justice considerations may require further rationing based on such considerations as the nature of the rights in issue, the complexity of the case, and the potential consequences for the litigant if they were unrepresented.

If this public cab rank is combined with a liberalization of the market so that lawyers could, within the limits of discrimination law, reject clients then some wealthy unpopular clients might also need to obtain representation via the rank. A question arises whether unpopular clients should be able to take advantage of regulated fees on the public cab rank because they were unable to find a private lawyer willing to represent them? It is submitted that because the primary purpose of the rank is to guarantee legal representation, and regulated fees are only a mechanism to facilitate this right for poorer clients, clients who have the capacity to pay market rates should be charged equivalent of market rates. This might be achieved by increasing the fees charged to the client (above the regulated fee) on a pro rata basis taking account of additional eligible income of the prospective client, capped at a 
maximum of the lawyer's standard market rate. ${ }^{94}$ This approach would also have the advantage of deterring a flight to the public cab rank by persons seeking to take advantage of the regulated fees offered: wealthier litigants would still end up paying substantial fees and, of course, would lose the opportunity to choose their own lawyer. A subsidiary question would then arise: how to distribute the additional fee income obtained from wealthier litigants using the rank? An obvious place would be the lucky legal service providers allocated to represent them, but this raises the prospect of some lawyers earning more from fulfilling their universal service obligation than others purely as a matter of chance. An alternative would be for the additional fee income to be invested back into the cab rank to meet administration costs and help subsidize additional legal representation.

Administering a cab rank rule for persons unable to obtain private legal assistance would involve significant running costs: reviewing the eligibility of those applying to use it, matching clients with suitable lawyers, setting rates and monitoring professional compliance. However, all legal aid services already perform this function for those applying for legal aid, while most law associations already administer pro bono schemes of one kind or another. ${ }^{95}$ The systems that are needed to make a limited USO work are already in place in many countries, and certainly both England and Australia.

\section{iii) Should legal advice be covered?}

An important question in designing a USO is whether it ought to cover legal advice. The Legal Profession Uniform Conduct (Barristers) Rules 2015 limits the cab rank rule to

\footnotetext{
${ }^{94}$ There are precedents for such individual costs assessments. For 50 years between 1949 and 2000 legally aided parties in England were protected by the legal aid shield, which gave the court power to decide the amount of adverse costs, if any, that would be reasonable for an individual to pay having regard to all the circumstances including the financial resources of the parties: Legal Aid Act 1988, s.17(1).

${ }^{95}$ See e.g The English Bar's Pro Bono Unit (http://www.barprobono.org.uk/overview.html). Ex ante assessments of the amount of legal work required in each case are made by the courts in England through cost budgeting: see e.g CPR 3.12-3.15.
} 
appearances in court. ${ }^{96}$ The risk of prejudicing legal proceedings obviously does not exist in in purely advice contexts. However, the rule of law requires that people have access to legal advice even before a dispute arises, not least to avoid the possibility of a dispute arising. ${ }^{97}$ Similarly, there are many lawyers who do not do any court work, and requiring them to participate in a cab rank geared exclusively to legal representation might be undesirable and unfair given their lack of experience. On the other hand there are many non-lawyers who regularly provide legal advice (eg accountants) who would not be subject to this USO, thus raising the prospect of unfair competition. This is a difficult issue, but while the legal profession enjoys certain privileges not available to non-lawyers providing legal advice, it would be possible to justify the extension of the USO to lawyers who do not do court work, and to allow lawyers to fulfil their USO through legal representation or advice or a combination thereof.

Legal advice in this context needs to be carefully defined. For the purpose of legal professional privilege (or client legal privilege) legal advice has been defined broadly to cover "conduct" or "strategy advice" in a "relevant legal context. ${ }^{98}$ Providing strategy advice is neither a core nor unique function of lawyers, and difficult to justify as a professional ideal. Who lawyers choose to dispense their 'wise counsel' to - or even to lobby for as in British American Tobacco example in part II - is entirely a matter for the individual lawyer, and it is submitted it should be beyond the scope of the cab rank rule in whatever form it takes.

\section{iv) Partial precedents}

Not only do most advanced legal systems have the tools and infrastructure to provide a regulated cab rank, there are also partial precedents for such a proposal. For example, in Australia several governments link the award of legal service work from government

\footnotetext{
96 The Legal Profession Uniform Conduct (Barristers) Rules 2015, Rule 17 states ' A barrister must accept a brief from a solicitor to appear before a court...'

${ }^{97}$ Three Rivers District Council [2004] UKHL 48, [2005] 1 AC 61.

${ }^{98}$ Ibid; AWB Ltd v Cole (No 5) [2006] FCA 571, (2006) 155 FCR 30; Betfair Pty Limited v Racing New South Wales [2009] FCA 1140.
} 
departments to a requirement to carry out a specified amount of pro bono work. In Victoria law firms that become members of the Government's general and specialist panel of law firms, must commit at least five percent of value of total hours billed under the contract to pro bono work. Firms that commit to undertake more pro-bono work, up to 15 percent of hours billed, receive points that make it more likely they will be awarded the tender for government work. If a firm fails to meet its commitment, the scheme provides that firms must make a payment to Government in lieu of their obligation. In practice, firms have been permitted to make up the commitment in a subsequent year. ${ }^{99}$ This feature of the Victorian scheme reveals one of its comparative strengths compared to the existing cab rank rule - it is considerably easier to enforce. The New York Bar also requires lawyers to engage in a set amount of pro bono work as a condition of admission to the bar. ${ }^{100}$ Other American States are planning to adopt similar rules in their own jurisdiction. Singapore has also recently moved to make the reporting of pro bono hours compulsory for all practicing lawyers. ${ }^{101}$

These precedents are only partial because the amount of pro-bono work carried out by lawyers in these schemes is either contractual, voluntary, or a requirement of legal training. Moving to a regime where some "public interest" work would be compulsory for all practicing lawyers would be a highly controversial step. In Singapore, the Committee to Study Community Legal Services Initiatives, set up by the Ministry of Law, noted in 2013 that there was no consensus within the profession regarding mandatory pro bono. ${ }^{102}$ The Australian Productivity commission also stopped short of recommending pro bono work be made compulsory, stating that this would be inappropriate because pro bono work is not

\footnotetext{
${ }^{99}$ For a description of both the Victorian and Commonwealth schemes, see Australian Pro Bono Centre 'Pro Bono Requirements in Government Tender Arrangements for Legal Service' (Available at http://probonocentre.org.au/provide-pro-bono/government-tender-arrangements/) 10022 NYCRR $\$ 520.16$. All persons admitted to the New York State Bar after 1 January 2015 must perform fifty hours of qualifying pro bono service.

${ }^{101}$ Singapore Ministry of Law, 'Mandatory Reporting for Legal Pro Bono Work' (Press Release) 24 March 2014 (Available at https://www.mlaw.gov.sg/content/minlaw/en/news/press-releases/mandatory-reporting-forlegal-pro-bono-work-done.html) 102 ibid.
} 
free. ${ }^{103}$ The proposal outlined here would not compel a lawyer to provide their services for free, rather it would restrict the fees they could charge and the freedom to choose who to act for while working on the 'cab rank', as a condition of them being granted the right to practice.

The effect of creating a limited USO would be that the profession, and ultimately those litigants who can afford to pay market rates for legal assistance, shoulder a greater share of the burden of funding access to justice than is currently the case. Some lawyers will oppose compulsory cross-subsidization in principle, but so far as the justice system is concerned, that train has already left the station. For example, in March 2015 the UK Government introduced 'enhanced' court fees for money claims worth more than $£ 10,000$, such that litigants will be paying court fees above cost, calculated as a percentage of the value of the claim. The Government has committed itself to investing the surplus generated by these 'enhanced fees' into other parts of the justice system. ${ }^{104}$ One of the paradoxes in the access to justice debate is that parts of the legal service market in both the UK and Australia are gold standard and extremely profitable. The UK legal services market had an estimated turnover of $£ 30.6$ billion in $2013 .{ }^{105}$ Partial cross subsidization of public services by those who use them is a funding model that Governments are increasingly likely to turn to as an alternative to full subsidization by taxpayers, and a limited universal service obligation that applies to all legal service providers and funders is worth exploring as a means of redistributing some of the wealth generated by England's world class legal system to help bridge the access to justice gap experienced by many.

\footnotetext{
103 Productivity Commission (n 5) p 33.

104 The Government has set a court fee of $5 \%$ of the value of all money claims worth more than $£ 10,000$ capped at a maximum of $£ 10,000$ : The Civil Proceedings and Family Proceedings Fees (Amendment) Order 2015, SI 2015/576. For the Government's policy position see Ministry of Justice, 'Enhanced Court Fees - The Government Response to Part 2 of the Consultation,' cm8971, January 2015.

105 The City UK, 'UK Legal Services 2015' (Available at https://www.thecityuk.com/research/uk-legalservices-2015-legal-excellence-internationally-renowned/)
} 


\section{Conclusion}

We know from experience that wealthy clients with unpopular causes are able to retain leading law firms without the cab rank rule, but we also know that for ideological reasons or due to social (and perhaps economic) pressures, some lawyers would decline to represent people who genuinely need legal representation. Although the cab rank rule does not guarantee legal representation to any one, it does enshrine a valuable professional ideal that no one who needs representation should be denied it. Crucially we also know that there is a massive justice gap or deficit felt by the 'missing middle' who can neither afford private lawyers and nor are they eligible for public legal aid, and in its current form the cab rank rule does nothing for this group, and may even make their position marginally worse. This paper has argued that the rule could and should be reframed to make a meaningful contribution to access to justice for all persons who have a genuine need for legal representation but have not obtained it, for whatever reason. This includes the creation of a limited universal service obligation, in which all practicing lawyers must dedicate a percentage of their billable hours to representing clients who have not been able to secure legal representation in the market place, for a regulated fee. This public cab rank could also be extended to licensed litigation funders. Outside this public cab rank, the usual market forces should prevail, subject to antidiscrimination law, with all the specialization, innovation and efficiencies that go with it. 